\title{
Seasonal and Altitudinal Prevalence of Fascioliasis in Buffalo in Eastern Nepal
}

Ramesh Prasad Sah ${ }^{1 @}$, Hari Kumar Prasai ${ }^{1}$, Jiban Shrestha ${ }^{2}$, Md Hasanuzzaman Talukder ${ }^{3}$, AKM Anisur Rahman ${ }^{4}$ and Ram $\mathrm{Bali} \mathrm{Sah}^{5}$

\author{
${ }^{1}$ Agricultural Research Station (Nepal Agricultural Research Council, NARC), Pakhribas, Dhankuta, Nepal; @ : \\ rpsnarc@yahoo.com;https://orcid.org/0000-0003-4221-1503; (DHKP <hkprasai60@gmail.com> \\ ${ }^{2}$ National Commercial Agriculture Research Program, NARC, Pakhribas, Dhankuta, Nepal; 〈jibshrestha@gmail.com> \\ ${ }^{3}$ Department of Parasitology, Faculty of Veterinary Science, Bangladesh Agricultural University, Bangladesh; \\ <talukder05@gmail.com> \\ ${ }^{4}$ Department of Medicine, Faculty of Veterinary Science, Bangladesh Agricultural University, Bangladesh; \\ <arahman_med@bau.edu.bd> \\ ${ }^{5}$ RARS, NARC, Tarahara, Sunsari, Nepal; <rambali_shah@yahoo.com>
}

Received 26 Dec 2017, Revised 28 Jan 2018, Accepted 5 Feb 2018, Published 28 April 2018

Scientific Editors: Neena Gorkhali, Tek Bahadur Gurung

Copyright (C) 2018 NARC. Permits unrestricted use, distribution and reproduction in any medium provided the original work is properly cited.

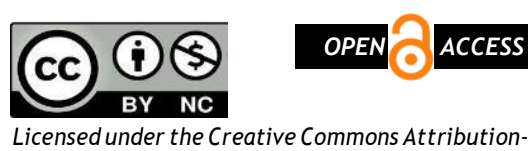
Licensed under the Creative Commons Attribution-
NonCommercial 4.OInternational (CCBY-NC 4.0)

\begin{abstract}
Buffalo is the most important livestock commodities for milk, meat production and several other multipurpose uses distributed densely from southern tarai to northern mid-hills in Nepal. Among several internal parasitic diseases fascioliasis is highly economic one caused by Fasciola in buffaloes. However, there are only few studies carried on prevalence of fascioliasis emphasizing buffaloes in relation to seasonal (summer and rainy, and winter) and altitudinal variations. Therefore, we examined prevalence of fascioliasis seasonally and vertically. For the purpose, we selected two districts of eastern Nepal and sampled from low altitude area known as Madhesha ranging from 175-200, Dhankuta from 800-1200 m, and Murtidhunga from 1800-2200 m elevation from the sea level, representing tarai, mid hills and high hills, respectively. Altogether from February 2013 to January 2014 at every two months interval we collected 798 fecal samples from buffaloes; 282 from Murtidhunga, 239 from Dhankuta and 277 from Madhesha. The samples were examined microscopically for the presence of Fasciola eggs using sedimentation technique. Results showed that overall prevalence of fascioliasis in buffaloes was 39.9\% (319/798), ranging highest 42.6\% in Madhesha followed by 39.7\% in Murtidhunga and $37.2 \%$ in Dhankuta, respectively. The prevalence of fascioliasis was found to be significantly $(\mathrm{p}<0.05)$ high in winter $(44.9 \%)$ comparing to rainy season $(34.4 \%)$. The prevalence of fascioliasis in buffaloes was relatively higher in low altitude than high altitude, although it was not statistically significant $(\mathrm{p}<0.05)$. In our findings the female buffaloes showed higher prevalence for fascioliasis than in male. Since the fascioliasis in buffaloes is highly endemic, thus strategic deworming in high risk period is recommended along with measure to prevent pasture contamination with buffalo feces.
\end{abstract}

Keywords: Altitude, Buffalo, Season, Fascioliasis, Dhankuta and Sunsari districts

सारांश

फासियोलिएसिस एक महत्वपूर्ण आन्तरिक परजिवी फसियोलाबाट हुने रोग हो। यो रोगको अध्ययन ई.सं.२०१३-१४ मा धनकुटा र सुनसरी जिल्लाका विभिन्न समुद्री सतह भन्दा उचाईहरुमा पालिएका भैंसीहरुमा जम्मा ७९६ वटा गोबरको नमना तीन वटै ऋतुहरुमा संकलन गरी अध्ययन गरियो। नमुना हरु प्रत्येक २ महिनाको अन्तरमा संकलन गरि प्रयोगशालामा फासियोलाको अन्डा परिक्षण गरियो। फलस्वरुप ३९.९\% भैंसीमा फासियोला भएको देखियो सो मध्ये ४२.६\% मधेशा सुनसरीमा, ३७.२\% धनकुट्टामा र ३९.७\% मुर्तिढुड़ामा पाइयो। यो रोगको प्रकोप जाडो याममा बढि ४४.९\% र कम उचाईमा ४२.६\% भएको देखियो। तिनवटै ठाउँहरुमा रांगो हरुमा भन्दा भैंसीमा यो रोग बढी पाइयो। फासियोला सबै ठाउँहरुमा भएको तर ऋतु र उचाईका आधारमा केहि फरक हुन्छ, भन्ने निष्कर्ष आयो। रोकथामको लागि चरणमा सुधार ल्याउनुका साथै यो रोग बिरुद्ध समय समयमा रांगा र भैंसीलाई औषधि खुवाउनु पर्दछ।

\section{INTRODUCTION}

Buffalo (Bubalus bubalis) is one of the important livestock commodities especially in South Asia including Nepal (Mahato and Harrison 2005). According to the MoAD (2016), there were about 6.4 million heads of buffalo in Nepal by the year 2015. Buffaloes are considered as "black gold" among livestock farmers because of its higher value in their livelihood and income generation. The buffalo contributes about $67.7 \%$ of the total milk production and $57.4 \%$ of the total meat production in Nepal (MoAD 2016). Buffalo suffers from various parasitic, viral, bacterial and fungal diseases. Parasitism reduces animal efficiency and productivity (Harrison 
2000, Vercruysse and Claerebout 2001, Khan et al 2011). Fascioliasis is one of the important diseases caused by internal parasites (Harrison 2000) which inhabit in liver of host (Nguyen et al 2017).

Fascioliasis, commonly known to cause by liver fluke, is the most important infection in buffalo caused by two species of trematode: Fasciola hepatica and F. gigantic (Nyindo and Lukambagire 2015). The F. hepatica species occurred almost throughout the world, but predominates in temperate zones, while $F$. gigantica is found in most continents, primarily in tropical regions (Andrews 1999, Bennemaet al 2014). Both species are transmitted in livestock by the snails of the family Lymnaeidae with potentiality to acute and chronic infection with expected blood loss of about 0.2-0.5 ml/worm/animal/day (Khan et al 2009, 2011; Nguyen et al 2017). Mahato and Harrison (2005) observed that the prevalence ranged from 30-70\% in buffaloes in Nepal. It is an emerging parasitic infection, impacting substantially on both veterinary and human health worldwide (Lazaraet al 2010). Infestations of Fasciola in ruminants cause heavy loss irrespective of geographical boundaries posing serious concern on the socio-economic of livestock farming in terms of milk and meat production (Saleha 1991) as well as human health (Nyindo and Lukambagire 2015). The occurrence of fascioliasis might be influenced by a multiple factors such as host, parasite and environment (Maqbool et al 2002). In past, few studies have already reported the prevalence of fascioliasis from many parts of Nepal (Mahato and Harrison 2005, Joshi 1988). However, prevalence of this disease in buffalo in relation to altitudinal variation and seasons has rarely been carried out. Hence, we estimated the prevalence of fascioliasis in buffaloes at various altitudes and seasons in from eastern Nepal.

\section{MATERIALS AND METHODS}

Study Area

For the present study, three locations of eastern Nepal belonging to two districts (Figure 1A) of eastern region were selected because these places were known to possess relatively higher density of buffaloes. The study locations were differentiated into three agro ecological zones to know the variation of prevalence representing high hill, mid hill and lowland or plain (tarai). The highest altitude from where samples were collected located at the range of about 1800-2200 meter above sea level (masl) in Murtidhunga (high hill, 27 $07^{\prime} 64.87^{\prime \prime} \mathrm{N} ; 87^{0}$ 36' 37.94" E); 800-1200 masl in Dhankuta (mid hill, 260 97'09.96" N; 87 34'31.09" E) of Dhankuta District and 175-200 masl in Madhesha (low land, $26^{\circ} 63^{\prime} 43.79$ " N; $87^{\circ} 18^{\prime} 60.72$ " E) of Sunsari District. Farmers raised buffaloes as semi-intensive type of management. Majority of farmers offered straw and grasses as feed. Only limited farmers provided commercial feed along with local feed materials to buffaloes.
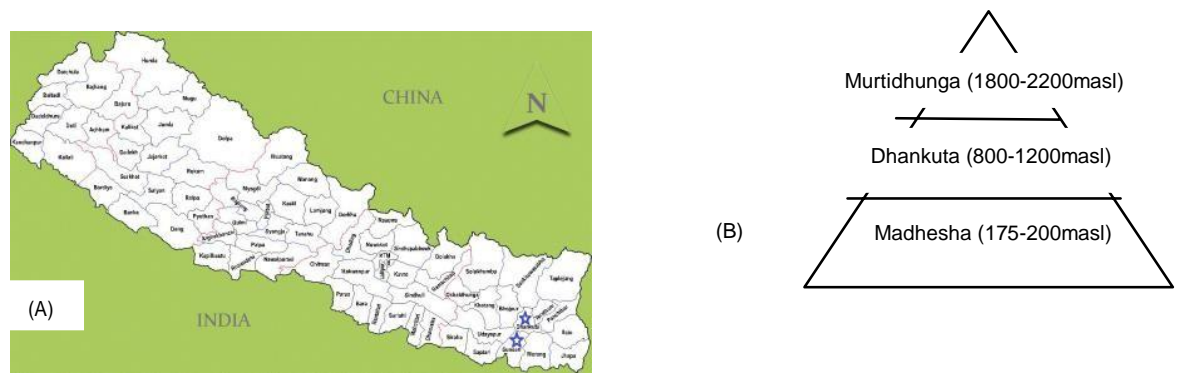

Figure 1. Map of Nepal showing studied districts depicted with star signs (A), and altitudinal locations of the study area (B).

\section{Study Design}

A total of 798 fecal samples were collected randomly from buffaloes aged above 1.5 years in different three sites from February 2013 to January2014 for 12 months. Breeds of buffaloes were local and Murrah cross. The samples were collected from buffalo dairy farms and household animals of three different sites of Dhankuta and Sunsari Districts namely Murtidhunga $(n=282)$, Dhankuta $(n=239)$ and Madhesha $(n=277)$ representing three different altitudes, high hill, mid hill and lowland agro-ecological zones, respectively (Fig 1A, B). Samples were collected in every two months interval representing into three viz. summer (March to June), rainy (July to October) and winter (November to February) from the same locations

\section{Laboratory Examination}

Fecal samples were collected per rectum from the buffaloes. Each samples of 5-10 g of fecal material was collected in clean polythene bag containing $10 \%$ formalin as preservative. The samples were properly labeled and brought to the laboratory of Agricultural Research Station, Pakhribas, Dhankuta, Nepal. The samples were tested microscopically for the presence of fluke (Fasciola) eggs using sedimentation technique (Soulsby 1983). 
Statistical Analysis

Data were compiled in Microsoft Excel using R 3.4.2 packages for analysis. The relationship of altitude with prevalence of fascioliasis and season were investigated. Spearman's Chi-square Test was used at the level of $\mathrm{P}<0.05$ to compare the effect of season and altitude on the prevalence of fascioliasis in buffaloes.

\section{RESULTS}

Fascioliasis in buffaloes was prevalent in all seasons and in all altitudes. The overall prevalence was found to be $39.9 \%$ (319/798) as shown in Table 1. The overall prevalence of fascioliasis was significantly $(\mathrm{p}<0.05)$ higher in winter season in comparison to rainy season.

Table 1. Prevalence of fascioliasis in buffaloes in different seasons from the study areas

\begin{tabular}{cccccc}
\hline Season & $\begin{array}{c}\text { Positive/ Tested } \\
\text { animal }\end{array}$ & Prevalence \% & $\begin{array}{c}\text { 95\% Confidence } \\
\text { interval (CI) }\end{array}$ & Chi-square test & p-value \\
\cline { 1 - 4 } Summer & $106 / 263$ & 40.3 & $34.36-46.57$ & 6.2327 & 0.0443 \\
\cline { 1 - 3 } Rainy & $89 / 259$ & 34.4 & $28.52-40.49$ & & \\
\hline Winter & $124 / 276$ & 44.9 & $38.91-51.0$ & \\
\hline Overall & $319 / 798$ & 39.9 & $36.56-43.48$ & \\
\hline
\end{tabular}

The prevalence ranged from $39.3 \%-41.7 \%$ in summer; $28.3 \%-40 \%$ in rainy and $36.5 \%-57.4 \%$ in winter season in buffaloes (Table 2). In low altitude tarai the prevalence of fascioliasis was significantly $(\mathrm{P}<0.05)$ higher in winter in comparison to rainy season.

Table 2. Seasonal prevalence of fascioliasis in buffaloes in different altitudes

\begin{tabular}{|c|c|c|c|c|c|}
\hline Season & Positive/ Tested animal & Prevalence \% & $95 \% \mathrm{CI}$ & $\begin{array}{c}\text { Chi-square } \\
\text { test }\end{array}$ & p-value \\
\hline \multicolumn{6}{|c|}{ Murtidhunga (1800-2200 masl) } \\
\hline Summer & $37 / 94$ & 39.3 & $29.44-49.98$ & \multirow[t]{3}{*}{0.01} & \multirow[t]{3}{*}{0.9959} \\
\hline Rainy & $32 / 80$ & 40.0 & $29.20-51.56$ & & \\
\hline Winter & $43 / 108$ & 39.8 & $30.52-49.68$ & & \\
\hline \multicolumn{6}{|c|}{ Dhankuta (800-1200 masl) } \\
\hline Summer & $31 / 78$ & 39.7 & $25.34-46.14$ & \multirow[t]{3}{*}{0.32} & \multirow[t]{3}{*}{0.8506} \\
\hline Rainy & $31 / 87$ & 35.6 & $25.65-46.62$ & & \\
\hline Winter & $27 / 74$ & 36.5 & $20.31-39.76$ & & \\
\hline \multicolumn{6}{|c|}{ Madhesha (175-200 masl) } \\
\hline Summer & $38 / 91$ & 41.7 & $30.08-50.56$ & \multirow[t]{3}{*}{16.23} & \multirow[t]{3}{*}{0.0003} \\
\hline Rainy & $26 / 92$ & 28.3 & $19.36-38.61$ & & \\
\hline Winter & $54 / 94$ & 57.4 & $46.82-67.59$ & & \\
\hline
\end{tabular}

The prevalence of fascioliasis in buffaloes was relatively higher in low than higher altitude; however, the prevalence was not significantly different (Table 3). The prevalence of the facioliasis was higher in female comparing to male in all the study sites (Figure 2).

Table 3. Prevalence of fascioliasis in buffaloes in different altitude level from the study area

\begin{tabular}{lccccr}
\hline Altitude (masl) & Positive/Tested animal & Prevalence \% & 95\% CI & Chi-square test & p-value \\
\hline $1800-2200$ & $112 / 282$ & 39.7 & $33.96-45.69$ & 1.55 & 0.4609 \\
\hline $800-1200$ & $89 / 239$ & 37.2 & $31.09-43.70$ & & \\
\hline $175-200$ & $118 / 277$ & 42.6 & $36.70-48.66$ & & \\
\hline
\end{tabular}




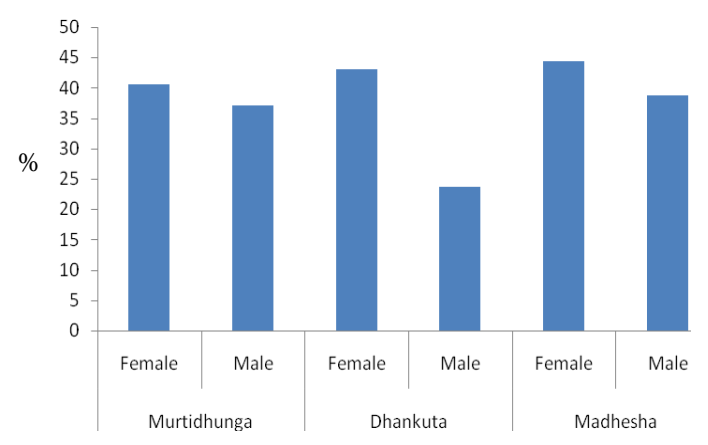

Figure 2. Fascioliasis infestation prevalence in male and female buffaloes in the study area

\section{DISCUSSION}

We showed that fascioliasis prevalence in buffaloes persisted almost round the year in the study sites. The overall prevalence of fascioliasis was $39.9 \%$ in buffaloes with higher prevalence recorded in winter $(44.9 \%)$ than in summer and rainy seasons (Table 1 and Table 2). It is possible that the buffaloes were exposed to Fasciola infection at least 2-3 months earlier i.e. in the monsoon season as have been indicated elsewhere by Khan et al (2017). These findings indicated that infection might be supported by monsoon seasons when the temperature and moisture levels were the most favorable both for the vector snails and Fasciola developmental stages (Khan et al 2017). Our results showed agreement with the findings reported by Singh (2001) in Uttar Pradesh India and Bhutto et al (2012) in Pakistan.

The prevalence of fascioliasis was found to be significantly $(\mathrm{P}>0.05)$ associated with season in our study. The Fasciola eggs observed in fecal test actually released into the soil and water, where the infection in the form of cyst enters into the animal through grazing along with grass, straw, drinking water into the stomach of buffaloes (Nguyen et al 2017). Moreover, no restriction on animal importation from outside, movement between the infected localities, grazing and feed materials to animals may also responsible for endemic infestation (El-Bahy 1998). Earlier, Mahato and Harrison (2005) reported prevalence of fascioliasis ranging from 30-70\% in buffaloes in Nepal. Joshi (1988) found above 50\% prevalence of fascioliasis from cattle and buffalo in six villages of mid-western hills of Nepal. Other studies have shown 48.7\% (Jithendran and Bhatt 1999), 50\% (Molina et al 2005), 44.7\% (Liu et al 2009) and 50\% (Siddiki et al 2010) prevalence from various countries. Such variations in fascioliasis infection are known to occur due to management practices, presence of intermediate hosts, intermediate hosts in localities, and meteorological differences such as humidity, temperature and rainfall patterns (Bhutto et al 2012).

Our data showed there was no significant difference in the prevalence of the fascioliasis in higher mountain and the tarai lowlands, but more prevalence of $42.6 \%$ vs 37.2 in tarai vs $39.7 \%$ in high hills occurred in present study (Table 3). This result might be arbitrary because we assumed that intermediate host of the Fasciola, the snails probably occur more frequently in tarai, however, infection were seen in high hills as well. Future studies might require examining the prevalence of intermediate host towards higher uplands as well.

The lower altitude was represented by Madhesa situated from 175 to 200 masl, there was significantly $(\mathrm{P}>0.05)$ higher percentage of fascioliasis in winter season (Table 2). This was probably due to abundant low sub-tropical irrigated rice cultivated areas as Copeman (1999) had observed higher prevalence of fascioliasis in buffalo in rice cultivated areas in Indonesia. In our study female buffaloes had higher facioliasis prevalence than in the males. It might be due to number of reasons, as buffaloes in winter or dry seasons were fed with rice straw as common practice all over Nepal even in high hills that could be the reasons of prevalence of the fascioloasis in high hills. The other reasons could be because there were higher numbers of female animals in the study areas, mostly kept for milking purpose by feeding the rice straw, in general. It is likely that dried straw fed to buffaloes might play important role to carry the dormant stages of fasciliosis parasites as Mahato et al (2000), Mahato et al (2005), Harrison (2005) and Nguyen et al (2017) described higher disease prevalence in stall fed buffaloes in rice producing areas. Since the male animals were generally sold and slaughtered for meat purpose, therefore disease infection might have been represented poorly in data pool. Since there is limited studies showing the relationship between fasciolosis and nutrition (Harrison 2000) future research should also be focused on such important aspects. 


\section{CONCLUSION}

Fascioliasis in buffaloes is endemic and wide spread in study areas of Nepal but seasonal and altitudinal variation occurs. Control measures should be taken for destruction of intermediate host (snail population). Periodic anthelmintic treatment should be given for getting maximum productivity from the buffaloes. Strategic deworming in high risk period like winter season in low land (Madhesha) is recommended along with measure to prevent pasture contamination with buffalo feces.

\section{ACKNOWLEDGEMENT}

Acknowledgement goes to Zoonosis Control Project (ZCP) of Nepal Agricultural Research Council (NARC) for fund the present study.

\section{REFERENCE}

Andrews SJ. 1999. The life cycle of Fasciola hepatica. In: Fasciolosis. Bull. Anim. Health Prod. Afr. 23(1): 57-86. Bennema SC, RGC Scholte, MB Molento, C Medeiros and OS Carvalho. 2014. Fasciola hepatica in bovines in Brazil: Data availability and spatial distribution. Rev. Inst. Med. trop. S. Paulo.56(1): 35-41.

Bhutto B, A Arijo, MS Phullan and R Rind. 2012. Prevalence of fascioliasis in buffaloes under different agroclimatic areas of Sindh Province of Pakistan. International Journal of Agriculture and Biology.14(2): 241-245.

Copeman DB. 1999. Fasciolagigantica Information. Accessed from http://www.jcu.edu.au/school/bms/ micro/fasciola/fasciola.htm

El-Bahy NM. 1998. Strategic control of Fascioliasis in Egypt. Review article. Continual Scientific Committee of Pathology, Microbiology and Parasitology, Egypt.

Harrison LJS. 2000. Interaction between Fasciolosis and nutrition in growing ruminants, Project jointly funded by DFID Livestock Production and Animal Health Programmes, Final Technical Report ZC-0008, https://assets.publishing.service.gov.uk/media/57a08d77e5274a31e0001894/R6608a.pdf

Jithendran KP and TK Bhat. 1999. Epidemiology of parasitoses in dairy animals in the North West Humid Himalayan region of India with particular reference to gastrointestinal nematodes. Trop. Anim. Heal. Prod. 31: 205-214.

Joshi BR. 1988. Prevalence of Fascioliasis (Liverfluke) in cattle and buffaloes in the Mid-western hills of Nepal. J. Inst. Agri. Anim. Sci. 9(1): 111-114.

Khan M, AKMA Rahman, S Ahsan, AEhsan, NN Dhand and MP Wards. 2017. Bovine fascioliasis: risk factors and spacetime clusters in Mymensingh, Bangladesh.Veterinary Parasitology: Regional Studies and Reports. 9: 104-109.

Khan MK, MS Sajid, MN Khan, Z Iqbal, M Arshad and AHussain. 2009. Bovine fasciolosis: Prevalence, effects of treatment on productivity and cost benefit analysis in five districts of Punjab, Pakistan. Res. Vet. Sci. 87: 70-75.

Khan MK, MS Sajid, MN Khan, Z Iqbal, M Arshad and A Hussain. 2011. Point prevalence of bovine fasciolosis and the influence of chemotherapy on the milk yield in a lactating bovine population from the district of Toba Tek Singh, Pakistan. J. Helminthol. 85: 334 - 338.

Lazara R, A Vazquez, I Domenech and LJ Robertson. 2010. Fascioliasis: Can Cuba conquer this emerging parasitosis? Trends Parasitol.26: 26-34.

Liu Y, F Li, W Liu, RS Dai, YM Tan, DS He, RQ Lin and Q Zhu. 2009. Prevalence of helminthes in water buffaloes in Hunan province, China. Trop. Anim. Heal. Prod. 41: 543-546.

Mahato SN and LJS Harrison. 2005. Control of fasciolosis in stall-fed buffaloes by managing the feeding of rice straw. Trop. Anim. Heal. Prod. 37: 285-291.

Mahato SN, LJS Harrison and JA Hammond. 2000. Overview of Fasciolosis-an economically important disease of livestock in Nepal Fasciolosis 2000 - Nepal Strategies for feed management in areas endemic for Fasciolosis, https://pdfs.semanticscholar.org/9a49/a8405f9fc0b7e3a9e5d431d459f83362874a.pdf

Maqbool A, CS Hayat, A Tanveer and HA Hashmi. 2002. Epidemiology of fasciolosis in buffaloes under different managemental conditions. VeterinarskiArhiv. 72: 221-228.

MoAD. 2016. Ministry of Agriculture Development Nepal, Agriculture Diary, 2016.

Molina EC, EA Gonzaga and LA Lumbao. 2005. Prevalence of infection with Fasciola gigantica and its relationship to carcass and liver weight, and fluke and egg count in slaughter cattle and buffaloes in southern Mindanao, Philippines. Trop. Anim. Heal. Prod. 37: 215-221.

Nguyen NT, TC Le, MD CoVo, HV Cao, LT Nguyen, KT Ho, QN Nguyen, VQ Tran and Y Matsumoto. 2017. High prevalence of cattle fascioliasis in coastal areas of ThuaThien Hue province, Vietnam. Available from: https://www.researchgate.net/publication/316602991_High_prevalence_of_cattle_fascioliasis_in_coastal_areas_of_Th ua_Thien_Hue_province_Vietnam [accessed Apr 03 2018].

Nyindo M and AH Lukambagire. 2015. Fascioliasis: An Ongoing Zoonotic Trematode Infection, 2015, BioMed Research International, Article ID 786195, 8 pages, http://dx.doi.org/10.1155/2015/786195

Saleha AA. 1991. Liver fluke disease (Fascioliasis): Epidemiology, Economic impact and Public health significance. Southeast Asian J. Trop. Med. Public Heal. 91: 361-364.

Siddiki AZ, MB Uddin, MB Hasan, MF Hossain, MM Rahman, BC Das, MS Sarker and MA Hossain. 2010. Coproscopic and haematological approaches to determine the prevalence of helminthiasis and protozoan diseases of Red Chittagong Cattle (RCC) breed in Bangladesh. Pakistan Vet. Journal. 30: 1-6. 
Singh BP. 2001. Parasitic infection in farm animals in different climates: In Climate in Relation to Livestock Production and Health. CAS in Veterinary Physiology, IVRI, Izatnagar, Bareilly, Utter Pradesh, India, pp. 36-37.

Soulsby EJL. 1983. Helminths, Arthropods and Protozoa of Domesticated Animals. $7^{\text {th }}$ edition, Lea and Febeiger, Philadelphia, USA, pp. 763-777.

Vercruysse J and E Claerebout. 2001. Treatment vs. non-treatment of helminth infections in cattle: defining the thresholds. Vet. Parasitology. 98: 195-214. 